\title{
Colonial Figures: Memories of Street Traders in the Colonial and Early Post-colonial Periods
}

\author{
SHERI LYNN GIBBINGS AND FRIDUS STEIJLEN
}

\begin{abstract}
$\mathrm{M}$ emories of the colonial era have been examined with great interest in the fields of history and anthropology, with scholars analyzing what is remembered, why and how the 'colonial experience' is located in popular memory. However, these perspectives have not addressed how the memories of different social types - such as street traders - are used to distinguish between different historical periods. This article focuses on memories that Dutch/IndoEuropeans shared about Indonesian street vendors. Their narratives are analyzed to show how street vendors mark political, social and economic transformations in their memories. We discuss and juxtapose stories from the early colonial period, the Japanese occupation, the Independence era and the post-colonial period to reveal how street
\end{abstract}


traders are employed to illustrate commensuration between self and other.

One of the major debates in memory studies focuses on the extent to which memories are products of individual agency or shaped by larger collectives. ${ }^{1}$ For instance, Maurice Halbwachs has argued that people 'acquire their memories' in society and that society also shapes the recalling of these memories at a later time. ${ }^{2}$ Recent studies have called for an examination into the social practices through which individual and social memories become entangled. Jennifer Cole, in particular, is critical of scholars that focus on memories as either individually constructed or collective representations. Instead, she maintains that memories exist 'intersubjectively, stretched across individuals and the wider social and cultural environment that they inhabit. ${ }^{3}$ Shared memories exist across individuals and collectives, but a growing number of scholars have noted the importance of recognizing that memories are multiple and competing. ${ }^{4}$

While some scholars have located the 'sites of memory' in bodies places, or objects, certain key figures - such as street vendors - are also 'sites' that contribute to solidifying individual biographies and shared history. Street vendors are among the few Indonesians that European and Indo-European husbands, wives and children regularly encountered in the Dutch East Indies. In a different context, Kate Bangall has noted that hawkers were one of the primary vehicles through which Chinese men and White women encountered each other in Australia. ${ }^{5}$ Those living in the Dutch East Indies, across generations, genders and occupations, shared a common experience with street vendors. As a result, we argue that hawkers have become a way to 'ground' memories and experiences both collectively and individually.

According to Pamela Pattynama, in the Indisch literature ${ }^{6}$ - both fiction and non-fiction - memory plays an important role in painting a picture of the Netherlands East Indies and the colonial era. ${ }^{7}$ Much of this genre is written in a realistic style as 'disguised ego documents' presenting adventures and experiences of the writers themselves. ${ }^{8}$ Domestic and family life often plays an important role as well. Pattynama has noted that 'remarkably often narratives revolve around fond representations of pleasurable interracial contacts. Reminiscences of shared affections between colonized and colonizers recur again and again. ${ }^{9}$ In a similar fashion, the memories of street vendors we describe illustrate how the Dutch nostalgically remember relations in ways that makes their racial domination appear innocent and obscure the marginal position of street traders. 
Another important theme in Indisch literature is the Second World War and the Japanese occupation. As Elsbeth Locher-Scholten points out, this literature came in waves. ${ }^{10}$ Immediately after the war, between 1945 and 1950, a significant number of memoirs were published. Then the flow of personal literature dried up to make way for scientific studies on decolonization and the integration of migrants from the Indies into the Netherlands. In the 1980s memory and victimhood of war were politicized and a new wave of personal literature was published. ${ }^{11}$ In the beginning of this millennium, a large number of personal accounts were published due to a Dutch government special funding project called 'the Gesture. ${ }^{12}$

In most of this literature street vendors are not present or at most they appear in a very insignificant role, as part of the décor. Some stories about street vendors can be found, however, in the Indisch journal Tong Tong. ${ }^{13}$ Most of the stories involve anecdotes about buying merchandise or funny encounters with street vendors. The marginal role of street vendors in these stories is shown in the following excerpt:

Everybody has his own memories. Sometimes the unimportant things, that for some reason left an impression, are lingering in your memory. I sometimes remember the toekang klontong who came cycling one day to the pasanggrahan in Sempol East Java. ${ }^{14}$

Street vendors have not been the focus of scholarly writing on memories of the Dutch colony. Pamela Pattynama described how the concubine, or nyai, was 'idolised for being the loving, nurturing nanny ('better' than white mothers), [while] on the other hand she was portrayed as the threatening embodiment of exotic dirty sexuality par excellence. ${ }^{15}$ Ann Stoler and Karen Strassler have also shown that servants were viewed as nurturing and filthy, lazy and untrustworthy. ${ }^{16}$ The dominant rhetoric, however, was one of intimacy. ${ }^{17}$ Rather than accepting the nurturing narratives at face value, Stoler and Strassler juxtapose the narratives of the Europeans to those of their servants to 'unsettle our certainty about what constituted the colonial and how it figures in people's memories today. ${ }^{18}$

While Stoler and Strassler illustrate the very different forms Indonesian servants' memories can take in comparison to those of the Dutch, our work focuses on how street vendors were 'stable signifiers' for the Dutch/Indo-Europeans and how they were used to mark differences between historical periods. While Stoler and Strassler compare the narratives of these two different groups - the Dutch and the 
servants - and situate them in relation to the present - authorized versions of history - our work compares the narratives of a single group, the Dutch/Indo-Europeans, in relation to a single figure - the street vendor - over different periods within the colonial and post-colonial eras. We suggest interpreting the significance of the street vendors not only in terms of the politics of the present, but also in relation to other figures and their meanings.

To undertake this project, we draw on Joshua Barker and Johan Lindquist's 'figures of modernity' approach. ${ }^{19}$ This approach argues that the significance of these individuals can be interpreted against social, political and cultural change. In this work, individuals are understood as 'key figures'. Barker and Lindquist show, for example, that the pakar telematika, or information and communication technologist, stands for the shifting tensions between media and credibility, and the street vendor stands for the expanding shopping malls. Following this framework, we use the figure of the street vendor to interpret memories of the colonial elite over a period of thirty years, examining how street traders are creatively constituted as subjects of nostalgia.

We refer to these narratives as nostalgic because many of them entail a fond remembering of the past. As William Cunningham Bissell says, 'Although nostalgia is fueled by a sense of modernity as rupture, hardedged and historically discontinuous, collective remembrance typically emerges out of efforts to forge a shared (if illusory) sense of group identity, cohesion, and long-term continuities. ${ }^{20}$ Many of those interviewed encountered harsh realities in the Dutch East Indies and their stories of the vendors must be understood in relation to their efforts to portray and remember positive interactions with Indonesians. The nostalgic reconstructions of the past can be understood as a disruptive commentary on the idea that the Dutch and their relations with Indonesians were always negative and oppressive. In a related manner, we also refer to these memories as a type of 'reinvention'. To do so is to not dismiss them as false or insignificant, but to recognize that both politics and culture shapes the form and content of these memories.

Although the memories of hawkers in the Dutch East Indies have not been studied, Bagnall has written about Chinese hawkers and White women in Australia. Even though boundaries and borders separated the Chinese from the White society, there were nevertheless 'contact zones,' and relationships - both friendly and sexual -were developed between Chinese men and White women. In particular, Bagnall argues that Chinese hawkers interacted with White women near the women's homes: 
The doorway, or front gate, represents the threshold between a number of real and imagined spheres - between the domestic/private sphere of the home and family and the public sphere of business, politics and commerce; and between the racially divided sphere of the Chinese and Whites who in fact existed within the same physical spaces. $^{21}$

Bagnall explores how White society imagined interracial contact, the fears such contact generated, and how reactions to it were gendered. In a similar way, we are interested in how the Dutch/Indo-Europeans imagined and talked about their interracial relationships with street hawkers, who were primarily Indonesian.

Between 1997 and 2001, interviews were completed with 724 individuals with the purpose of recording the end of the Netherlands colonial presence in Asia. ${ }^{22}$ The interviews focused on people's experiences in the Netherlands East Indies and Indonesia between 1930 and 1960. Although almost all interviewees were living in the Netherlands or Belgium at the time of interviewing, they represent different categories from the colonial upper class. In 2011, we reviewed the transcripts of all 724 interviews in search of conversations involving street traders. The interviewees had not been asked any systematic or specific questions about street traders; these figures simply emerged during discussions of daily life in Dutch East Indies. As we show in this article, particular shared stories emerged during different historical moments and helped individuals to distinguish between the different periods.

From our search we collected 32 interviews that discussed street traders in significant depth. Of these, 15 of the interviewees were totok (White) and 15 were Indo-Europeans. The remaining two individuals were of Moluccan and Chinese descent. All of those interviewed considered themselves to be culturally and socially Dutch or European. We therefore describe them interchangeably as Dutch or Indo-European in the article. The 724 individuals interviewed occupied different positions in the colony, varying from plantation managers and military officials to civil authorities. In general they occupied high-ranking positions and were therefore not considered 'working class' while they lived in the Dutch East Indies. This particular group includes individuals who had the means and ability to return to the Netherlands because they Dutch citizenship or were given equal rights.

Due to space constraints, in this article we draw on 14 of the interviews that discussed street traders in depth. Nine of the 
interviewees included identified themselves as Dutch and three as IndoEuropean (though in their interviews they identified themselves as Dutch). One individual was Moluccan; his father worked for the Colonial administration.

During the collection of these narratives, we were struck by how the stories of street traders revolved around fond representations of pleasurable interracial contact and exchange. Each story was personal and unique, but they were united in their descriptions of the relationships between elites and traders during different periods.

Street vendors could have been susceptible to a wide range of interpretations, yet our research indicates that stories of street vendors across the interviews were similar. The figure of the street vendor allowed individuals to collectively differentiate between diverse eras in the Dutch East Indies, and bring order to these different periods. The traders were remembered as a social type that transgressed politics and represented the neutrality of the economic sphere as a place for shared communication. The narratives of street traders revolve around fond representations of pleasurable contact and communication with the traders. Unlike memories of servants or nyai, which complicate the link between European and indigenous worlds, ${ }^{23}$ memories of street vendor simplified that link. Memorial traces of street vendors must be viewed in relation to the general representation of interracial contacts produced in the (post) colonial period, as part of the larger complex of 'innocent' images of interracial contact. ${ }^{24}$

\section{SOUNDS, MOVEMENTS AND TYPES: THE COLONIAL ERA BEFORE 1942}

Most of the Dutch colonials living in the Dutch East Indies bought luxury goods from European shops but purchased basic food items from marketplaces or door-to-door sellers. In narratives from before the Second World War interviewees remember friendly encounters with street vendors, and specifically their movements, sounds and forms of communication. The street vendors were remembered for supplying the Dutch with everyday necessities. As many participants suggested, it was through their distinctive sounds that one knew even before they became visible which kind of street vendor was approaching. Some of the interviewees explicitly referred to the sounds and tried to reproduce them, bringing their narratives to life.

Mrs Van Roon-Koek (b1924) grew up in Bandung. She knew a few Malay words, most of which were associated with what the street vendors sold. She could also tell what type of vendor was arriving by the noises he made: 
Yes that is beautiful, all these things KEMBANG PLIEM. Kembang is the Malay word for flowers, so he first called kembang and then KEMBANG PLIEM, and he carried, how do you call it? A pole with baskets, a pikoelan. In the baskets he had his flowers. All kind of flowers; [they were] very beautiful. You could always hear who was in the street, the Chinese; he ticked on a bamboo wood BAMI TOCK TOCK, a special click. BOT-BOTOL, that is the junk dealer. All these small calls. What is more, they also sold food on the street; it was strictly forbidden that we bought some. Because it could make you ill. But if you are born there, like me... We did not dare to buy; we sent the servants, but 'don't get sambal,' because that was too spicy for us. And then she came with a pisang [banana] leaf with that food that she had bought for us. For just a half a cent, so we sometimes 'ate from the street.' Not very often. They came with a lot of bottles with syrup in their baskets.

Interviewer: It must have been heavy? Yes you could see him sweeping and bowing. They also had a specific way of walking to compensate for that. That is the image of early morning; you can still see it on films, when the people come from the mountain with all their merchandise with their pikoelans to bring to the market. ${ }^{25}$

Mrs Van Roon-Koek's narrative described the Malay words for the items sold, and the mechanism, sounds and movements of the traders in detail. She described how they did not refer to the traders by name but by the sounds they made, which represented what they sold. Finally, she noted that the image of the trader carrying a pole was common and could still be seen in films. Her narrative celebrated the activities of the street traders, not as individuals, but as a social type that was part of everyday life in the Dutch East Indies. To have lived in the Dutch East Indies was to know the words, sounds, and movements of small traders.

Mrs Van der Els-Vertregt (b1928) discussed the street vendors in relation to the numerous other people who visited her house regularly. In her narrative, street traders were once again represented as part of everyday life, but were remembered as social types:

Frequently we had visitors, all Europeans... And of course there were always these travelling vendors that came to the door. That was in the Indies a lot. Such as a vendor with textiles... And there were seamstresses that travelled around. And the sate seller came frequently; he came at 
irregular times and came to the garden. We had a large garden, and then he asked through the servants if we wanted sate. If that was the case, we ordered one hundred or two hundred at once, because it was small ones, smaller then we have nowadays. And that grilling, he brought everything on a carrier made of wood. He had everything with him: the meat on the skewers, the arang, the charcoal, to grill. He sat in the garden in the evening. That was very cozy, and then everyone had as much as he/ she wanted. ${ }^{26}$

Mrs Van der Els-Vertregt, like other interviewees, remembered the frequency of the different vendors' visits to her door. She described the distinctive types of vendors but quickly focused in on the sate seller, describing the process of grilling and recalling specific Malay words. These general descriptions of traders situate them as social types rather than individuals. For some individuals, servants served to mediate between the traders and the Dutch, but the traders were nonetheless remembered for their tools. For Mrs Van der Els-Vertregt, the street vendors were an integral part of how she remembered everyday life in the Dutch East Indies before the war.

While some interviewees remembered ordering or bargaining through servants, many recalled the process of negotiating directly with the traders. Mr Goudswaard (b1921), born of Dutch parents, grew up in the Netherlands Indies. He remembered how his mother liked to bargain when buying Chinese porcelain:

I have a lot of memories of those guys who came to the door who carried pots and pans and plates in their selendang, and that my mother could sit for hours and tawar [bargain] with them. Whether or not such a plate would cost one guilder and fifty, or forty, or twenty-five cents. And the endless scenes where the seller would walk away saying that he could not live from that [amount], or my mother went away saying, 'I don't have time for this.'... I have learned to tawar, and when we were married for twenty-five years we went back with our children to Indonesia and the Philippines, and in Indonesia I made big scenes to tawar to the surprise of my children. ${ }^{27}$

Mr Goudswaard, like others, remembered the specifics of the interactions between the traders and his mother, and specifically the process of bargaining, which was done for fun, not because it was 
necessary. For Mr Goudswaard, the street vendors invoked nostalgia for an innocent past in which economic transactions represented a point of communication and exchange between Dutch/Indo-Europeans and Indonesians. In their description of the Malay words used and the process of bargaining, these narratives illustrate mutual understanding. Although the traders were a distinct social type, they were represented as an important site of positive interracial contact and exchange. These memories of interacting with the vendors are a nostalgic reinvention of interracial relationships in the Dutch East Indies.

Deborah Poole has described how 'type photographs' became popular during the latter part of the nineteenth century. Many of these type photographs came from colonial states and circulated as commodities to be collected.$^{28}$ In Indonesia a large number of photographs and cartes de visite (postcards) depicting street traders were circulated. In these images the traders were classified by the type of merchandise they sold. ${ }^{29}$ Discourses about street traders before 1942 mirrored the representations found in these photographs. Traders were described as social types, not as individuals or close friends. The narratives, however, establish the presence of traders as part of the fond memories of life in the Dutch East Indies.

\section{ON OUR SidE: THE JAPANESE OCCUPATION, 1942-1945}

Street vendors during the Japanese occupation are remembered not only for their role in commercial exchange but also for helping the Dutch get through this difficult period. In narratives about this period, the sounds, movements, and actions of the traders are no longer important; instead the accounts shift to focus on how it was difficult for the Dutch to access traders, and when they did, the traders made sacrifices for them. In the context of this changing political landscape, street vendors came to occupy an important place in the formation of shared memories, appearing as helpful in contrast to the dangerous Japanese. These narratives produce an idyllic representation of the interracial contact between Dutch and Indonesians during the Japanese occupation. In this process of memory making, street vendors have come to stand for the positive relations that the Dutch had with Indonesians in general.

Everyday life in the Dutch East Indies changed dramatically after the invasion by the Japanese army. The Japanese occupied the former Dutch colony from February 1942 to August 1945 and approximately 42 000 Dutch military personnel were made prisoners-of-war (POWs) and detained in labor camps. Europeans were interned and the Japanese tried to win the hearts of Indonesians with their slogan 'Asia for the Asians'. 
Around 100000 European and Indo-European civilians, including many children, were imprisoned in camps and faced undernourishment and difficult conditions. ${ }^{30}$ Japanese occupation policies had a radical influence on the relationships and contact between Europeans, IndoEuropeans, and Indonesians. Dutch memories from this period include stories of street vendors 'helping' them to access food. In these narratives, the relative absence of traders on the street was also used to capture the abnormality of the times. Despite the Japanese being opposed to Dutch occupation of the region, these narratives suggested that street vendors and perhaps other Indonesians supported the Dutch.

Mr Challik (b1916) was the son of an Indo-European bookkeeper. He entered the military service in 1942 and was taken as a POW by the Japanese. From October 1942 to August 1945 he worked as a riveter in a dockyard. He recalled his duty in the harbor in Makassar at the beginning of the war and his attempt to buy food from a street vendor under watch of the Japanese:

The first day on duty I had to trim coals, a big basket with the two of us, bring it up to the ship and empty it, and then [bring it] back again. Then came a vendor, an Indonesian with a bicycle with two long baskets full of cooked duck eggs at the back. He tried to sell them to us. We still had some money; it was at the end of the month and we still had some money. So we asked, 'Can we buy the eggs?' The Japanese guard looked around [and signaled] like 'go ahead.' I ate ten eggs that day. I thought what I can get now they cannot take away from me. ${ }^{31}$

In many of the narratives, the appearance of street vendors illustrated how life in the Dutch East Indies had gone awry. Before the arrival of the Japanese, the Dutch had made purchases - directly and through the domestic servants - from street vendors who came to their door. But after the occupation these interactions were under close watch by the Japanese, and there was uncertainty about whether such transactions would be allowed to continue.

As living conditions became worse during the Japanese occupation, the 'cheap economy' that the street vendors represented became the life jacket for those who needed to cut costs. This was the case for Mrs Bekkering-Berkhout, who was born in Batavia in 1928 to an IndoEuropean mother. During the war her family was not interned, and they survived by buying food from street vendors. The mother was left 
bargaining with a series of new street vendors who appeared at their doorstep:

We lived for one guilder a day for the whole family in the beginning of the war. It was so cheap; for one gobang, that is $2.5 \mathrm{cent}^{32}$ you bought gado gado [traditional peanut sauce meal]. My mother was good at bargaining; you could not buy luxury [goods], but for eating and drinking it cost one guilder a day. We had a cabinet and in the upper drawer with the paper guilder, and in the course of the day the toekang sajoer came and it was changed, and then that toekang and that toekang, and at the end my mother said proudly: I managed it today again. ${ }^{33}$

In many of these narratives bargaining was remembered in a different manner than during the pre-war period. No longer 'for fun,' bargaining became a matter of survival. Although many remembered having to bargain with little money, those interviewed did not portray the street traders in a negative light. In many narratives, the traders were imagined as on their side, trying to help them get the food they needed.

Mrs Carels-Lijnis Huffenreuter (b1912) recalled the role of street vendors during the occupation period for helping to bring food covertly, behind the backs of the Japanese:

We lived in a street where everybody knew each other. And we of course helped each other. But nobody had or owned anything. I was privileged because I had that bakery where the sellers came if they could, because they were not allowed to sell to the Europeans. But it was also their living... Where they got it I don't know but they brought it to us because they thought we needed it. And they thought 'we have always had our living from the Dutch but now we are not allowed to sell to them anything anymore.' They thought: 'later we can't sell anymore, therefore we will bring this now to them.' They had a large tin Klim that was milk powder. They got it somewhere and brought it to us, and then they had other cans, maybe from the Japanese, and they said take this because soon you won't have anything to eat. So they helped us. And they had dried meat. That way we had food. ${ }^{34}$

Mrs Carels-Lijnis Huffenreuter's access to the vendors was at first functional, through her bakery, but this came to be used as a disguise for 
other deliveries. In contrast to the pre-war memories, she remembered the traders not by their sounds, movements or selling techniques, but by their efforts to help the Dutch. In particular, in this narrative we start to see how the thoughts and motivations of traders were imagined and described. The Dutch imagined the traders as wanting to sell to them for economic purposes, but later in the narrative the traders were depicted as wanting to ensure the Dutch had food to eat.

Mrs Vaillant-Brocx (b1932) discussed street vendors during the beginning of the war and during her internment in a house with seventeen other family members. Her stepmother strained to feed everyone on a small budget. She described how a charcoal seller brought them rice when he could because their ration was not enough:

We were cooking on charcoal, and we had a toekang arang, that is the seller of charcoal. He came with two of these big baskets with a pikoel to bring the charcoal. He was a smart guy. In some way or another he could get hold of rice and he told my mother, 'aunties and uncles, I have managed to get some again.' That of course did not fall on deaf ears: 'okay bring it.' They were prepared to pay enough because the ration we had was not enough. So they agreed on a time and he said: 'I'll be there on that day and that time make sure the small gate is open and I can enter the back garden directly and close the door behind me.' And then the beras, the rice, was under the charcoal. So we then bought the charcoal and the rice that he promised us. ${ }^{35}$

It is particularly noteworthy that in these narratives the Dutch started to recall the street vendors speaking like Dutch people. Rather than recounting their 'foreign' calls, the Dutch described the traders during this period as individuals with whom they engaged in conversations. Even though the traders were still remembered as social types - for example, the charcoal seller - they spoke like the Dutch and were imagined as 'smart' people.

In these narratives the merchandise of the street vendors became important for survival, rather than for leisurely consumption as described during the prewar era. The role of selling food during this difficult time signaled a different 'structure of feeling' marked by a sense of uncertainty characteristic of the time. ${ }^{36}$ The lack of regular visits between street vendors and the Dutch symbolized a major shift in this era, and the stories of street vendors became a means to mark this 
transformation. In wartime narratives, the street vendors functioned as a means to talk about hardship and deprivation.

The street vendors served as anchors during the tumultuous time of the Japanese occupation, ensuring the Dutch could meet their basic daily needs. The wartime narratives about street vendors, despite their shift in focus, thus still conform to the prevailing style, which depicted the vendors as familiar and helpful. However, memories about street vendors during the time of the Japanese occupation are marked by a shift in the form of communication between the two parties. In these memories, the Dutch described the traders' speech more often in Dutch than in Malay, and started to imagine their thoughts and motivations as well. Still, the narratives revolve around fond representations of interracial contact, as well as shared alliances between the colonized and the colonizer in opposition to the Japanese.

\section{IMAGINING THEIR THOUGHTS: THE INDONESIAN REVOLUTION, 1945-1949}

Following the Second World War and the declaration of independence by Indonesia, the Dutch government launched military campaigns to reestablish Dutch control. It was the beginning of four years of fighting between the Dutch and Indonesian nationalists. Dutch ex-internees from Japanese camps became victims of attacks by young Indonesian nationalists, and at the same time the Indonesians interned IndoEuropeans who had not been interned by the Japanese. In addition to many small fights there were three major clashes. The first was in October 1945, when Indonesian nationalists in Surabaya attacked British troops who were sent to Indonesia to take control. Then, after the arrival of Dutch troops from Europe, two broad military operations were undertaken in 1947 and in $1948 .{ }^{37}$

It was a time of mutual distrust between the Dutch and Indonesian nationalists. Both parties deemed street vendors to be suspicious because of their mobility. Specifically, some traders continued to have relations with the Dutch despite the boycott that had been placed on selling to them. Some traders were allowed to sell to the Dutch in the camps but it was highly regulated. The Dutch were suspicious that revolutionaries would pretend to be street traders to gain access to them. As illegal or assumed-to-be illegal goods moved around, a new group concerned with controlling street vendors announced itself: the pemoeda, or Indonesian revolutionaries. Public appearances and political identification were important, and patrols and neighborhood watches monitored the cities and countryside for possible traitors. ${ }^{38}$ 
Mr Claasen (b1926) grew up in Java, and was in secondary school when the war broke out. In his interview he discussed September 1945, just after the proklamasi and before the outbreak of large-scale violence. The district where he lived organized its own guards, but they were not able to prevent a number of attacks from being carried out by peloppers (scouts), the term used by the Dutch to refer to Indonesian fighters. $\mathrm{He}$ described how the street vendors who tried to sell food to the Dutch during the boycott put themselves at risk. He did not totally trust the sellers, because nationalists could also disguise themselves as traders to get access to the Dutch:

In the beginning of September the food boycott started. The Indonesians wanted to prevent farmers from outside bringing in their food to Bandung. And then, I don't know how it was organized, that somewhere at the periphery of the city, at a specific address there was a lot of food, which we then collected... It was a boycott for big towns in which the Indonesians wanted to prevent fresh stuff from outside being brought in by Indonesians, the farmers, to be sold in the city. It started that we were not allowed to go to the pasar, and the people there that did not sell anything anymore went into the streets, and that was, as much as they could, leading even to their murdering as I have heard. The peloppers, the republicans, the 'freedom loving mobs' tried to stop the supply of food... One time we stopped one; we checked him and he had two hand grenades under his merchandise. He was lucky to stay alive but we beat the hell out of him. ${ }^{39}$

The street vendor had become a figure that was closely policed. The Independence era was a time when both sides - Indonesian and Dutch were guarding the city, and the movement of street vendors and their contact with both sides made them suspicious. If the pemoeda were the guards of the nation, the street vendors were a group that needed to be watched because of their close association with the enemy. During this time, the Dutch remember the street vendors as innocent and portray them as wanting to help the Dutch, despite the nationalist restrictions.

Mrs Steinbach-van Reijn was born in Bandung in 1931. She discussed the revolutionary period and how their new Indonesian neighbors policed the movement of traders, but the traders still desired to help the Dutch: 
In their place an Indonesian family came and that was not very pleasant because during the hatred against the Dutch they controlled [the street vendors] from their verandah. In Indonesia it is normal that vendors with food or textiles come to your door, and at the end they [the nationalists] stopped them from coming with only their eyes. So they did not dare to come because the Indonesians had to stop the Dutch with a boycott. The Indonesian sellers did not want to hate us and wanted to get rid of their stuff. So they wanted to sell to the Dutch but did not dare. And to go to the pasar was dangerous for your life. Because there they sold human meat; it was what was said then. ${ }^{40}$

Similar to the Japanese period, the individuals interviewed about the Independence era remember the street vendors as people who they could understand - they began to imagine their motivations. The street vendors became a means for the Dutch to suggest that there was link between the European and indigenous worlds despite the nationalist opposition. Mrs Steinbach-van Reijn said: 'So they did not dare to come because the Indonesians had to stop the Dutch with a boycott.' Unlike the nationalists, street vendors appear as heroes in these memories, as the Indonesians who were not opposed to Dutch rule.

We find a similar depiction from Mr Limahelu (b1936), who described the period during bersiap in Surabaya in October $1945 .{ }^{41} \mathrm{He}$ remembered the scarcity of goods and traders' desire to sell to him:

We went to the pasar with my mother, but they refused to sell to us. The seller wanted to, but there were pemoedas in battle dress [sic]. One has a stranger uniform than the other. So the seller did not dare to sell. They are simple people, they just wanted to sell, but that was not allowed. And there were the servants. Our servants were not interned; they went home and then they waited to be sent back home. Very sad because these people also missed their income. ${ }^{42}$

Like others, Mr Limahelu claimed to know the inner desires of the sellers. But he went further and became their advocate, saying they missed their income because of the actions of their fellow Indonesians.

In the pre-war narratives, the Dutch and Indo-Europeans were already engaged in acts of translation and communication with the street vendors; in these later narratives, they extended the communication 
power beyond the language of tawar to suggest they knew what the street vendors wanted. These are 'acts of memory' that suggest street vendors and the Dutch could relate to each other across difference. The Dutch imagined themselves as able to interpret, speak to, and speak for the street traders in a context of radical linguistic and social alterity. The traders were not imagined as 'Malay speakers' but as Dutch-like, suggesting a weakness of the national identity. In other words, these stories raise moral ambiguity regarding the nationalist cause.

James Siegel argues that the discovery of identity was central to Indonesian Independence. In particular, there was a constant struggle with translation with the lingua franca that belonged to no one as the first language. He argues that individuals were thus involved in a process of putting oneself in another identity. ${ }^{43}$ The stories outlined suggest that the Dutch placed the street traders into other identities. In their memories, the Dutch altered the traders' identities, imagining them momentarily less as 'types' and more as Dutchmen. The positioning of the traders as 'Dutch-like' occurred during a time of political and social upheaval, and in this process put limitations on the social identity of the Indonesians. They became more like 'Dutch' than like their own people, the Indonesian nationalists, during the nationalist revolution.

\section{HELPING THE TRADERS: DECOLONIZATION, 1949-1958}

In December 1949, the Netherlands gave up its attempt to restore the colonial regime due to international pressure. Although many Dutch returned to the Netherlands, others stayed when the sovereignty of Indonesia was granted. Many Dutch enterprises continued running in Indonesia, and West Papua remained a Dutch colony. The dispute between Indonesia and the Netherlands over this region resulted in a worsening of their diplomatic relationship and deeper tensions between Dutch and Indonesians. In December 1957, Indonesian President Soekarno urged in a decree that all Dutch leave the country. Shortly after that, the Indonesian government started to nationalize Western-owned companies. Amidst these widespread transformations, street vendors continued to populate memories from this time. The social memories of street vendors in the post-colonial period in some sense rendered mute many other aspects of the colonial past, and rendered the informal economic sphere as an important site of remembering.

While power relations on a macro level had changed dramatically, the relationship between the street vendors and the Dutch after independence was narrated in a similar fashion to the pre-war and transitional narratives. One kind of memory that materialized again was 
the nostalgic recollection of the sounds and movements street vendors made as they walked through the streets. Mrs Ubels-Onvlee (b1926) told such a story. She was born in Sumba and married in 1951. She lived with her husband in the Indies until 1958. In 1955 they lived in Jakarta, and she remembered how she did not feel any animosity toward the Indonesians. For instance, her children enjoyed eating food from the street vendors:

They [the children] were also enthusiastic when the kwee poetoeh came. They already had their bath and were prepared to go to sleep, and then suddenly 'KWEE POETOEH.' That [vendor sold] steamed rice in small rolls with goela djawa [Javanese sugar] and rasped kelapa [coconut]. It was delicious. ${ }^{44}$

Sate was also glorified in the same way as during colonial times. The nostalgic representation of interracial contact returns to focusing on sights and sounds of the traders.

Mr Ammerlaan (b1918) arrived in the Dutch Indies in 1948 and worked for the naval pharmacy in Surabaya. Arriving shortly before the transfer of sovereignty, he had a different outlook than those who had lived in the Indies prior to the war, because he had not experienced the former colonial relations and hierarchy. Street vendors were part of what he found amusing and enjoyable about life in the Indies. Mr Ammerlaan, like his colonial predecessors, remembered the traders by their calls:

And then I was off. And then we would pay somebody a visit, or my wife sometimes went to the tennis court, and then I went there to watch or play there.

Interviewer: Did you have supper at the tennis court sometimes?

Oeh, [a sign of delightful memory] there was a sate seller, he called 'SATE CHICKEN, SATE CHICKEN, SATE

CHICKEN' and once in awhile there was a guy who had sate from, what is it, kambing, goat. But I did not like that sharp meat. Sate chicken I liked and the gentlemen and women who were playing tennis bought all his sate and we were eating sate with a nice glass of beer. ${ }^{45}$

Another informant who fondly remembered bargaining with street vendors after independence was Mrs Radius-Lantman (b1919). She worked as a midwife and housewife during her stay in Indonesia from 
1947 to 1958 and her husband worked for an oil company, which took them to Plaju, Banyubang and Balikpapan. In 1958 they left for the Netherlands, but before they left she experienced a strike by the servants and a house search. ${ }^{46}$ She explained how before the strike many street vendors came to her door with fresh fruit:

And there were also vendors at the door. Door, there was not a real door. There were open doors and then there was the verandah. There also was no bell; everything was open because that is the time without aircon [air conditioning]. So, they came and then they called sepada [siapa ada] that means 'is there somebody'? So there was a vegetable seller, and a lot of fruit. We had a very old woman selling fruit, her name was Emma. Many people were named after the royal family. Wilhelmina, Juliana, and Emma. We liked that. And you bought the fruit, mostly you bought fruit at the door.

Interviewer: You, yourself?

Yes, and then always you asked: boleh tawar. You had to tawar; if you did not then they thought she is not well. You always bought djeroek [oranges], every day we pressed djeroek. Every afternoon after resting we drank djeroek. Cooled in the refrigerator. ${ }^{47}$

Mrs Radius-Lantman fondly remembered bargaining and asking to tawar with the street vendors. This was a revitalization of the way connections were made with the indigenous in the colonial and transition eras: being able to tawar meant you could communicate with them. This communication, however, returned to focus only on the exchanges. The Dutch stopped speaking for and imagining what the traders wanted and desired.

Mr Kloosterman was born in 1908. In 1948 he became a primary teacher and school principal at a Dutch school in Jakarta until he was forced to leave in 1958. He described the good relations he and his wife had with the Indonesians and in particular with a vendor selling antiques. The stories shifted from the street vendors aiding them to the Dutch and Indo-Europeans also helping the traders:

There came a toekang antique [antique seller] with two boxes and he asked if we want to buy something. He had two things. One was a beautiful green ring, flower ring, which he later bought back and he had an ox-blood vase... He could still tell us how much we paid. Later on 
somebody wanted the flower ring and he came and said: 'you have paid so much; I will give you so much if you sell it back'... We were leaving for the Netherlands. So we said: 'then you have to take that back,' also which he did. But then it turned out he had other ideas. He asked us if he could leave his things with us. He did not dare to take them to the kampong because there they would be stolen. 'And if you keep them in your house I come back tomorrow.' For months until we left definitely, he left his stuff at our home and went without worrying to his own kampong because his merchandise was safe.

Mr Kloosterman described the relationship he had with another street vendor:

We also had a toekang boeah [fruit seller] who only sold bananas. He always came Monday morning when I was at school. He came to my wife, had a little chat, and also with the neighbor. And then he said, 'I don't have money to buy boeah [fruit]. Can you lend me five rupiah? I'll bring it back Saturday.' So who came back on Saturday? The toekang boeah to bring back the five rupiah with a sisir pisang [banana bunch] as a present. And my wife says, 'that is not necessary.' The other Monday he is back again. He wanted to borrow another five rupiah. And he did so until we left. ${ }^{48}$

While the traders were remembered for helping the Dutch in the Japanese occupation and Independence periods, the Dutch remembered themselves helping the traders during the post-colonial period. In this story we get a sense of a relationship that went beyond mere economic exchange. Mr Kloosterman's wife lent the trader money and he remembered how the money was returned along with a present.

The street vendors in these narratives serve to comment upon this particular historical moment as a return to normalcy, where transactions occurred with ease. The roles from the Japanese occupation and Independence era had been reversed - the Dutch were now helping the traders - but the relationship remained cooperative. One person hired a street vendor to work in his office; another stored a vendor's goods and lent money to another. Although people retained personal memories of the colonial and post-colonial past, memories were also collectively expressed through a shared discourse on Indonesian street traders that emphasized an ethos of communication, an ability to converse across 
difference in the economic sphere. These narratives simplified the interracial relationships between the Europeans and Indonesians by presenting the trader as an icon of positive relations. ${ }^{49}$

\section{Street Sellers AND Colonial Nostalgia}

In this article we analyzed Dutch/Indo-European narratives of street vendors, illustrating how street vendors became symbols for conceptualizing the social and economic changes from the colonial period through to post-colonial, independent Indonesia. We used the 'key figures' approach to show how a certain social type appeared differently in memories among a group of individuals who lived in the Dutch East Indies from 1930 to 1960. These interviewees shared a vocabulary about street traders, and our task was to analyze and interpret this vocabulary. We argued that street traders were a binding, significant and indicative social type whose appearance in the stories bound together certain ways of seeing and interpreting life since the colonial period. The people interviewed employed narratives about street vendors in order to discuss and at times critique social and political change between different moments in the colonial and postcolonial history of Indonesia.

We argued that street vendors were important figures in connecting people's local memories to collectives ones. They were Indonesians who the Dutch/Indo-Europeans from all walks of life encountered on a daily basis. As a result, street vendors connected individual stories to larger collective histories that were comprehensible across the group. In these collective memories, the street vendors remained constant in their friendliness, loyalty, and helpfulness as the narratives moved between contexts and historical periods. Interactions with traders - the languages they spoke, the food they sold, and the sounds they made - were part of everyday life and something anyone who lived in the Dutch East Indies could describe.

Although the overall portrait of interactions with the traders remained positive, there were differences. In the colonial period and the post-colonial period the traders were remembered primarily as social types and distinguished by their sounds, names, and movements. The interviewees used Malay words in their narratives from these periods and remembered bargaining with the traders in Malay. During the Japanese occupation and the nationalist period, the traders were imagined in a slightly different manner. The interviewees recounted specific conversations with the traders, and imagined what the traders were thinking and what they desired. The traders came to speak and 
appear more Dutch in these moments. In particular, during these tumultuous periods memories of kind, helpful street vendors were contrasted to the cruel Japanese and dangerous nationalists. In the postIndependence period, the traders were remembered again as 'type' and were recalled by the sights and sounds they made.

We argued for reading the significance of the street vendors not only in terms of the politics of the present but also in relation to figures and their meanings, and the changing historical context within the colonial and post-colonial periods. Despite the fact that street vendors were open to wide range of interpretations, the interviewees shared similar stories about them. By following the street vendor in the recollections of the Dutch and Indo-Europeans, we could clearly see how they assigned a generally consistent meaning to this figure across political, geographic and historical contexts. The street vendor served as a device to describe changes taking place, but to also to position the Dutch positively. As scholars, rather than using key figures as a metonymic device, we explored how those interviewed made street vendors stand as part of a culture and a shared experience, as well as a site of commensuration in a context of colonial relations. The memorial traces of the street vendors must be viewed in relation the general representation of interracial contact produced in the post-colonial period. Street vendors are part of the larger complex of 'innocent' images of interracial contacts.

\section{ACKNOWLEDGEMENTS}

We would like to thank Marieke Bloembergen, Abidin Kusno, Carmen Nave, and Katherine MacIvor for their comments on earlier versions of this paper. Any shortcomings in this final product are our own.

\section{ENDNOTES}

${ }^{1}$ Jeffrey K. Olick and Joyce Robbins, 'Social Memory Studies: From "Collective Memory" to the Historical Sociology of Mnemonic Practices', Annual Review of Sociology, vol 24, 1998, pp105140. Jennifer Cole, 'Narratives and Moral Projects: Generational Memories of the Malagasy 1947 Rebellion,' in Ethnos, vol 31, no. 1, pp95-126.

${ }^{2}$ See Lewis A. Cosers, Maurice Halbwachs: On Collective Memory, University of Chicago Press, Chicago, 1992.

${ }^{3}$ Jennifer Cole, Forget Colonialism?: Sacrifice and the Art of Memory in Madagascar, University of California Press, Berkeley, 2001, p29.

${ }^{4}$ Jennifer Cole, 'Narratives and Moral Projects: Generational Memories of the Malagasy Rebellion,' in Ethos, vol 31, no 1, 2003, pp95-126. David Berliner, 'An "impossible" transmission: Youth religious memories in Guinea-Conakry, American Ethnologists, vol 32, no. 4, 2005, pp576-592.

${ }^{5}$ Kate Bagnall, 'Across the threshold: White women and Chinese hawkers in the white colonial imaginary, Hecate, vol 28, no 2, p3.

${ }^{6}$ Indisch literature refers to a section in Dutch literature inspired by the Dutch East Indies; it includes colonial and postcolonial discourses.

${ }^{7}$ Pamela Pattynama, 'Het heden is de toekomst van het verleden. Indië als plaats van herinnering', in Jaarboek van de maatschappij der Nederlandse Letterkunde te Leiden 2009-2010, Maatschappij der Nederlandse Letterkunde, Leiden, 2011, p51. 
8 ibid.

${ }^{9}$ Pamela Pattynama, 'Memories of Interracial Contacts and Mixed Race in Dutch Cinema', Journal of Intercultural Studies, vol 28, no 1, 2007, p71.

${ }^{10}$ Elsbeth Locher-Scholten, 'In Nederland na "de verre oorlog". Publieke herinneringen aan de Tweede Wereldoorlog in Azië', in Remco Raben (ed), Beelden van de Japanse bezetting van Indonesië, Waanders/ NIOD, Zwolle/Amsterdam, 1999, p60.

11 ibid, p64.

12 'The Gesture' was meant to compensate for the cold welcome that people from the Netherlands Indies received after decolonization. See Fridus Steijlen, 'Het Gebaar', in M. de Keizer and M. Plomp, Een open zenuw: hoe wij ons de Tweeder Wereldoorlog herinneren, Uitgeverij Bakker, Amsterdam, 2010, pp190-199.

${ }^{13}$ Tong Tong, now called Moesson, has been published since 1957. It was and is the largest Indisch journal in the Netherlands.

${ }^{14}$ Franken, 'De Toekang Klontong', Tong Tong, 1 December 1977, pp19-24.

${ }^{15}$ Pattynama, op cit, p72.

${ }^{16}$ Ann Laura Stoler and Karen Strassler, 'Castings for the Colonial: Memory Work in 'New Order' Java', Society for Comparative Study of Society and History, vol 41, no 2, pp4-48.

${ }^{17}$ Elsbeth Locher-Scholten, 'So close and yet so far: The Ambivalence of Dutch Colonial Rhetoric on Javanese Servants in Indonesia, 1900-1942', in J. Clancy-Smith and F. Gouda (eds), Domesticating the Empire: Race, Gender, and Family Life in French and Dutch Colonialism, University Press of Virginia, Charlottesville, 1998, p141.

${ }^{18}$ Ann Laura Stoler and Karen Strassler, 'Castings for the Colonial: Memory Work in 'New Order' Java', Society for Comparative Study of Society and History, vol 41, no 2, pp4-48.

${ }^{19}$ Joshua Barker, Johan Lindquist, et al, 'Figures of Indonesian Modernity', Indonesia, no 87, 2009, pp35-72.

${ }^{20}$ William Cunningham Bissell, 'Engaging Colonial Nostalgia', Cultural Anthropology, vol 20, no 2, 2002, p226.

${ }^{21}$ Bagnall, op cit, p11.

${ }^{22}$ See Fridus Steijlen, Memories of "The East": Abstracts of the Dutch Interviews about the Netherlands East Indies, Indonesia and New Guinea (1930-1962), KITLV Press, Leiden, 2002. The interviews can be accessed at the Royal Netherlands Institute of Southeast Asian and Caribbean Studies in Leiden, the Netherlands: SMGI interview collection.

${ }^{23}$ Pattynama, op cit, p72.

${ }^{24}$ ibid, p74.

${ }^{25}$ Mrs P.A. van Roon-Koek, code number: 1411.1: track 11; 25 June 1999.

${ }^{26}$ Mrs A. van der Els-Vertregt, code number 1381.1: track 12; 24 August 1999.

${ }^{27}$ Mr J.M. Goudswaard, code number 1474.1: track 07; 4 November 1999.

${ }^{28}$ Deborah Poole, 'An Image of "Our Indian": Type Photographs and Racial Sentiments in Oaxaxa, 1920-1940', Hispanic American Historical Review, vol 84, no 1, 2004, p42.

${ }^{29}$ Kate Bagnall has also described how a drawing of a Chinese hawker with a pole over his shoulder was 'representative of the "typical" Chinese man in Australia', op cit, p1.

${ }^{30}$ See W. op den Velde et al, 'A cross-national study of posttraumatic stress disorder in DutchAustralian immigrants', Australian and New Zealand Journal of Psychiatry, vol 34, no 6, 2000, pp919-928 and Elly Touwen-Bouwsma, 'Japanese minority policy: The Eurasians on Java and the dilemma of ethnic loyalty', Bijdragen tot de taal-, land-en volkenkunde, vol 152, no 4, 1996, pp553-572.

${ }^{31}$ Mr M.A. Challik, code number 1576.1: track 08; 27 April 2000.

${ }^{32}$ Gobang is a coin with a hole in the middle used in the colonial era, worth 2.5 cents.

${ }^{33}$ Mrs P.H. Bekkering-Berkhout, code number 1275.1: track 07; 2 July 1998.

${ }^{34}$ Mrs A.W. Carels-Lijnis Huffenreuter, code number 1310.2: track 11; 20 November 1998.

${ }^{35}$ Mrs E.C. Vaillant-Brocx, code number 1166.1: 08; track 31 October 1997.

${ }^{36}$ Raymond Williams, The Long Revolution, Pelican, Hardmondsworth, 1961.

${ }^{37}$ See George Kahin, Nationalism and revolution in Indonesia, Cornell Southeast Asia Program Publications, Ithaca, NY, 2003; W. Frederick, Visions and heat: The making of the Indonesian revolution, Ohio University Press, Ohio, 1989, and Joop de Jong, Avondschot: hoe Nederland zich terugtrok uit zijn Aziatisch imperium, Boom, Amsterdam, 2011.

${ }^{38}$ Abidin Kusno, The Appearances of Memory: Mnemonic Practices of Architecture and Urban Form in Indonesia, Duke University Press, Durham, NC, 2010, p267.

${ }^{39}$ Mr R.J. Claasen, code number 1160.2: track 18; 27 November 1997.

${ }^{40}$ Mrs E.R. Steinebach-van Reijn, code number 13561.1: track 08; 11 March 1999.

41 The first half year or more that was known to be a very violent and chaotic phase was referred to as 'bersiap' by the Dutch.

${ }^{42}$ Mr J.F. Limahelu, code number: 1365.1: track 08; 6 April 1999.

${ }^{43}$ James T. Siegel, Fetish, Recognition, Revolution, Princeton University Press, New Jersey, 1997. 
${ }^{44}$ Mrs C. Ubels-Onvlee, code number 1471.1: track 18; 21 October 1999.

${ }^{45}$ Mr L.P.J. Ammerlaan, code number 1336.1: track 16; 6 January 1999.

${ }^{46}$ The strike happed because of the increasing tensions between the Netherlands and Indonesia over West New Guinea in the 1950s. In Indonesia in 1957 the relation between Dutch and Indonesians became tense resulting in new boycotts against the Dutch and strikes in Dutch enterprises.

${ }^{47}$ Mrs J.W. Radius-Lantman, code number 1665.1: track 4; 10 October 2000.

${ }^{48} \mathrm{Mr}$ A. Kloosterman, code number 1615.2: 14-15; track 17 August 2000.

${ }^{49}$ The majority of the discussions by the interviewees were similar and in only one case did an individual refer to street vendor as cheating them. 